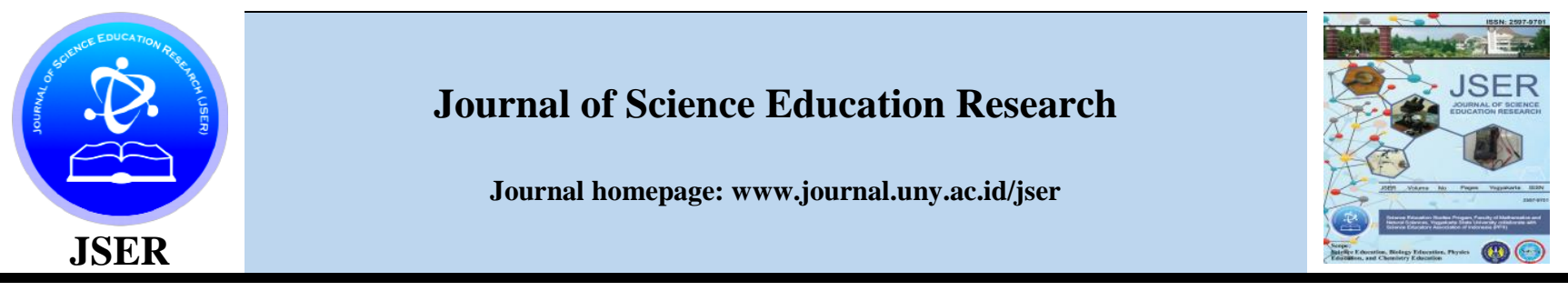

\title{
The Effectiveness of Science E-Modules for Class VII Junior High Schools Based on Socioscientific Issues to Improve Students' Critical Thinking Skills
}

\author{
Komang Edi Suastrawan*, I Nyoman Suardana, A.A.I.A. Rai Sudiatmika \\ 1,2,3 Science Education, Postgraduate Program, Ganesha University of Education, Singaraja \\ Corresponding Author. Email: komangedisuastrawan@gmail.com
}

Keywords:
e-modules, critical
thinking,
socioscientific
issues

Keywords:

thinking,

issues

\begin{abstract}
This study aims to analyze the effectiveness of science e-modules for class VII junior high schools based on socioscientific issues to improve students' critical thinking skills. The type of research used is Pre-Experimental with one group pretest-posttest design. This research was conducted at SMP Negeri 2 Seririt in class VII A with a total of 30 students. Data were collected with 12 items of critical thinking skills test on global warming material through pretest and posttest. Data were analyzed using Paired Sample T-Test and gain score test. The Paired Sample T-Test was used to calculate the significance of increasing students' critical thinking skills, but the gain scores were used to calculate the increase in students' critical thinking skills. The results of this research showed that there was a significant difference in students' critical thinking skills before and after used science e-module in learning (sig. $<0.05$ ). The normalized $\mathrm{N}$-gain test also showed an increase in students' critical thinking skills with a value of 0.55 in the medium category. Based on the results of the Paired Sample T-test and the normalized gain score, it can be concluded that the e-module based on socioscientific issues is effectively used to improve students' critical thinking skills.
\end{abstract}

C2021 JSER. Universitas Negeri Yogyakarta

\section{INTRODUCTION}

The rapid development of science and technology in the era of the industrial revolution 4.0 in various sectors of life provides its own challenges for every nation, including Indonesia. Indonesia is one of the countries located in Southeast Asia which has abundant human resources. The existence of abundant human resources must be supported by the development of quality, quality, and a good pattern of critical thinking to compete during the increasingly rapid industrial revolution 4.0. One of the components that play the most role in creating quality human resources and having a critical thinking pattern so that they can compete in the face of the development of industrial revolution 4.0 is education. In this regard, education in Indonesia must be in line with the development of industrial revolution 4.0 and 21 st-century learning. Industrial revolution 4.0 is marked by a very strong integration between the digital world and the field of industrial production. The very rapid development in industrial world also affects the world of $21^{\text {st }}$ century education. Learning in the $21^{\text {st }}$ century demands a change in orientation in learning, which not only prioritizes knowledge but also student skills. Learning in the $21^{\text {st }}$ century demands the development of four aspects of competence that must be mastered by students, such as communication, critical thinking, cooperation, and creativity (P21, 2019). In addition, the World Economic Forum (2016) identified 10 skills that must be mastered by students, one of which is critical thinking skills.

Technology-based learning in the era of the industrial revolution 4.0 demands the development of competencies that exist in $21^{\text {st }}$ century learning. One of the competencies that must be developed early on for students in digital-based learning in the era of the industrial revolution 4.0, namely critical 
thinking skills. Critical thinking is a reasonable thought to decide an action that must be taken (Ennis, 1991). Practicing critical thinking skills to students from an early age will make students have a critical thinking pattern in dealing with issues or phenomena that are increasingly easy to find in today's digital era. Students who have been trained to think critically from an early age will be able to easily distinguish issues that are hoaxes and issues that are true and then be able to find solutions to these issues.

Based on this paradigm, one of the most significant efforts has been made by the Indonesian government in supporting $21^{\text {st }}$-century learning, namely preparing regulations for national education standards that are implemented in the 2013 curriculum. The implementation of the 2013 curriculum provides great opportunities for the development of students' critical thinking skills. Permendikbud Number 20 of 2016, also stipulates Graduate Competency Standards (SKL) which state that every graduate of primary and secondary education units must have competence in three dimensions, such as attitudes, knowledge, and skills. One of the skills in question is critical thinking and acting skills. Apart from these efforts, to support learning in the digital era, the government issued Circular Letter Number 9 of 2018 which states that the Ministry of Education and Culture through the Center for Information and Communication Technology for Education and Culture (Pustekkom) has created a learning portal for teachers, students, and related parties, which is named Rumah Belajar. The "Rumah Belajar" is a free online learning portal that supports digital learning in the era of the industrial revolution 4.0 because it provides digital classes, electronic school books, learning resources with video, audio, and animation, question banks, virtual laboratories, space cruises, and cultural maps (Pustekkom, 2019). If teachers, education practitioners or learning practitioners can apply what the government has been trying to do, Indonesian students should have high critical thinking skills and be able to respond to scientific issues that developed in the era of the industrial revolution 4.0.

The fact shows that students' critical thinking skills in Indonesia are still relatively low. The survey results of the International Association for the Evaluating of Education Achievement (IEA) in Trends in Mathematics and Science Study (TIMSS) in 2015, proved that Indonesia was only able to rank 45 out of 48 countries with a score 397 lower than the international average score which is 500 . Based on the number of TIMSS scores, Indonesia is in the low international benchmark predicate which is the lowest rank in TIMSS, while the highest ranking in TIMSS is the advanced international benchmark. Martin et al. (2015) stated that students with low international benchmarks were only able to interpret pictorial diagrams or simple science concepts, while students with advanced international benchmark rankings mean that these students have been able to identify, communicate, predict/interpret, and draw conclusions about complex concepts. This showed that the material taught does not emphasize reasoning, so that as a result the critical thinking skills of Indonesian students are still relatively low. The results of the 2018 Program for International Student Assessment (PISA) survey which were attended by 600,000 participants from 79 countries, Indonesia's scores in the categories of reading, math, and science abilities were 371,379 , and 396. The 2018 PISA results have decreased from the 2015 PISA results in the three categories (reading, mathematics, and science). The PISA results also show that the quality of education and thinking skills of Indonesian students is still relatively low. In line with the results of the TIMSS and PISA surveys, the research conducted by Saputra et al. (2016) and Nuryanti et al. (2018) revealed that the critical thinking skills of junior high school students were in a low category.

The low critical thinking skills of students are caused by various factors, one of which is internal factors, that is students' prior knowledge (Hayudiyani et al. 2017). Prior knowledge has a role in determining students' critical thinking skills. Students who have high prior knowledge may not get difficulties in learning, while students who have low prior knowledge can have many difficulties in understanding the subject matter so that it has an impact on students' low critical thinking skills (Hayudiyani et al. 2017). In addition to prior knowledge, students' critical thinking skills are also influenced by other factors, that is learning resources that do not support the development of students' critical thinking skills. The main learning resources used by students and teachers are in the form of science textbooks and the learning media used do not describe abstract concepts (Yulizar \& Munzil, 2017). This is supported by the research of Artifasari et al. (2017) which states that practice questions in textbooks do not represent critical thinking and present more questions to measure student understanding. Nowadays teachers and students in schools use government-issued printed books and worksheets which only contain summaries and practice questions, so that students' critical thinking skills are not trained. This is supported by Parliani (2016) which states that teaching materials that only contain summaries and practice questions are thought to have not been optimal in improving students' critical thinking skills. Most of the textbooks in circulation are not all able to meet curriculum standards that can foster students' skills to be able to think critically, 
creatively, innovatively, communicatively and collaboratively (Yusliani et al, 2019).

Based on this, innovations in science learning are needed to support students' independent learning in the digital era, one of which is in terms of developing teaching materials in the form of emodules. E-module is one of the self-study materials presented in electronic format and connected by links as navigation, and is equipped with video tutorials, animations and audio presentations to enrich the learning experience (Kemendikbud, 2017). The use of e-modules that combine technology in learning provides a new learning experience for students, is very effective in increasing students' learning motivation, is suitable for use as independent study material, and is effective for improving critical thinking skills (Jufrida et al. 2020; Jaenudin, 2017; Serevina et al. 2018; Febrianti, 2017; \& Puspitasari, 2019). Laili et al. (2019) state that e-modules can be used to complement textbooks used by teachers in learning activities, help students learn independently, assist in explaining the subject matter, help measure students' understanding levels, and e-modules can reduce paper use. Based on these advantages, it is very important to develop a core e-module to support independent learning in the digital era and to support existing textbooks.

E-modules have been widely developed by previous researchers. Several researchers who have developed e-modules, namely Savira et al. (2019) Development of an e-module on momentum and impulse based on process-oriented guided inquiry learning (POGIL) to improve students' higher-order thinking skills, Serevina et al. (2018) regarding the development of Problem Based Learning (PBL) based E-Modules on heat and temperature materials to improve students' science process skills, Prime et al. (2017) the development of e-modules that combine science process skills and dynamic motion materials to improve students' critical thinking skills, and others. Based on the research on the development of e-modules that have been carried out, the development of science e-modules to date has only been limited to integrating e-modules with certain learning models. The development of science e-modules that have been carried out so far has not been linked to controversial socioscientific issues. In fact, in the era of the industrial revolution 4.0, students are very easy to find controversial issues in everyday life that are not yet clear. Therefore, the development of science e-modules based on socioscientific issues is very important.

Science e-modules based on socioscientific issues can be used as alternative solutions to improve students' critical thinking skills. Socioscientific issues are controversial social issues with conceptual ones that are closely related to science (Sadler, 2004). Evren (2018) also states that the advantages of SSI-based learning are learning becomes more meaningful, develops critical thinking skills, problem-solving, and reflective thinking, increases social awareness, supports character development, and contributes to students' scientific literacy. The development of science emodules based on socioscientific issues encourages learning that emphasizes processes and encourages students to actively discuss various socioscientific issues related to phenomena in real life, as well as looking for various alternative solutions to deal with these issues, thus indirectly generating students' learning motivation and critical thinking skills. This is supported by research by Rostikawati and Permanasari (2016) which shows that textbooks with the context of socioscientific issues are feasible and meet the requirements to be used in the science learning process and the implementation results show that these textbooks have a great influence and can improve literacy. students' science in terms of competence and attitude.

With regard to the problems described above, further research is needed regarding the Effectiveness of Science E-Modules for Class VII Junior High Schools Based on Socioscientific issues to Improve Students' Critical Thinking Skills".

\section{METHOD}

This research is a pre-experimental study with one group pretest-posttest design. This research was conducted on students of class VII A at Junior High School Number 2 Seririt which consisted of 30 heterogeneous students. The main data in this study are critical thinking skills data obtained through test instruments on global warming material. The critical thinking skills test used is in the form of description questions based on indicators from Facione (1990), namely interpretation, analysis, evaluation, inference, explanation, and self-regulation. The value of critical thinking skills before and after treatment were analyzed descriptively obtained from the conversion into a scale of 100 by comparing the scores obtained by students with the maximum score of critical thinking skills and multiplied by 100 .

The data analysis techniques used in this research are descriptive analysis and inferential statistical analysis. Descriptive analysis was used to describe the results of the pretest and posttest based on the average value, frequency distribution, and standard deviation using a benchmark reference assessment (PAP). The criteria used are according to Arikunto (2015), that is very good qualifications (SB) (80-100), good (B) (66-79), sufficient (C) (56$65)$, poor $(\mathrm{K})$ (40 -55), and very poor (SK) (0-39). Statistical analysis was used to test the hypothesis, namely the Paired Sample T-Test analysis using the SPSS 22.0 for Windows application at a significance 
level of $5 \%(\alpha=0.05)$. Before the data were analyzed using the Paired Sample T-Test, First, the data must meet the prerequisite test, namely the normality test using the Kolmogorov-Smirnov analysis with the help of the SPSS 22.0 application for Windows at a significance level of 5\%. In addition, the pretest and posttest scores were also analyzed with a normalized gain score to determine the improvement of students' critical thinking skills. The criteria used as reference to the normalized gain score according to Hake (1998), namely $(<\mathrm{g}\rangle) 0.7$ (high), $0.7>(<\mathrm{g}>) 0.3$ (medium), and $(<\mathrm{g}>)<0.3$ (low).

\section{RESULTS AND DISCUSSION}

The results of the descriptive analysis of prior critical thinking skills and critical thinking skills after treatment using a science e-module based on socioscientific issues are presented in Table 1.

Table 1. Results of Descriptive Analysis of Pretest and Posttest Values

\begin{tabular}{|c|c|c|c|c|c|}
\hline \multirow{2}{*}{ Mark } & \multirow{2}{*}{ Qualification } & \multicolumn{2}{|c|}{ Pretest } & \multicolumn{2}{|c|}{ Posttest } \\
\hline & & fo & $(\%)$ & fo & $(\%)$ \\
\hline $80-100$ & Very good & 0 & 0 & 12 & 40 \\
\hline $66-79$ & Good & 0 & 0 & 12 & 40 \\
\hline $56-65$ & Enough & 0 & 0 & 6 & 20 \\
\hline $40-55$ & Poor & 21 & 70 & 0 & 0 \\
\hline $0-39$ & Very Poor & 9 & 30 & 0 & 0 \\
\hline \multicolumn{2}{|c|}{ Amount } & 30 & 100 & 30 & 100 \\
\hline \multicolumn{2}{|c|}{ Average } & \multicolumn{2}{|c|}{43.61 (Less) } & \multicolumn{2}{|c|}{74.86 (Good) } \\
\hline \multicolumn{2}{|c|}{ Standard Deviation } & \multicolumn{2}{|c|}{6.26} & \multicolumn{2}{|c|}{9.80} \\
\hline \multicolumn{2}{|c|}{ Gain Score } & \multicolumn{4}{|c|}{0.55 (Medium) } \\
\hline
\end{tabular}

Table 1. shows (1) students' prior critical thinking skills are still relatively low, that is all students are in the less and very poor category. (2) The average value of students' critical thinking skills as a whole has increased after being taught with the Science e-module (3) The results of the average gain score of students' critical thinking skills as a whole is 0.55 in the medium category.
Furthermore, based on the results of the pretest and posttest that have been carried out, it is continued by conducting a descriptive analysis on each dimension or aspect of critical thinking skills to determine the achievement of each dimension of critical thinking skills. The description of the mean scores for each dimension of students' critical thinking skills pretest and posttest is presented in Table 2.

Table 2. Average Pretest and Posttest for Each Dimension of Critical Thinking Skills

\begin{tabular}{lcccccc}
\hline \multirow{2}{*}{ KBK Aspect } & \multicolumn{3}{c}{ Pretest } & \multicolumn{2}{c}{ Posttest } & \multicolumn{2}{c}{ N-Gain } \\
\cline { 2 - 7 } & Mark & Qualification & Mark & Qualification & $\langle$ g $\rangle$ & Qualification \\
\hline Interpretation & 42.50 & Poor & 75.83 & Well & 0.58 & medium \\
Analysis & 41.67 & Poor & 75.00 & Well & 0.57 & medium \\
Evaluation & 34.58 & Very Poor & 59.58 & Enough & 0.38 & medium \\
Inference & 42.08 & Poor & 72.92 & Well & 0.53 & medium \\
Explanation & 48.33 & Poor & 82.50 & Very good & 0.66 & medium \\
Self Regulation & 52.50 & Poor & 83.33 & Very good & 0.65 & medium \\
\hline
\end{tabular}

Table 2. shows (1) The pretest scores per indicator of students' prior critical thinking skills are in the very poor to poor category, while the posttest scores are in the moderate to very good category. (2) Gain scores on each indicator of critical thinking skills are all in the medium category. (3) The increase in the gain score of the lowest critical thinking skills occurred in the evaluation aspect.

The results of the prerequisite test showed that the data on critical thinking skills pretest and posttest were normally distributed (sig. > 0.05). Based on the results of the prerequisite test, it can be concluded that the critical thinking skills data from the research have met the requirements, so that hypothesis testing using the Paired Sample TTest can be done with a significance level of 5\% $(\alpha$ $=0.05$ ). The test criteria used are if the significance number obtained is smaller than the specified significance number $(\alpha=0.05)$, then $\mathrm{H}_{0}$ is rejected and $\mathrm{H}_{\mathrm{a}}$ is accepted.

The hypothesis to be tested in this study is $\mathrm{H}_{0}$, that is there is no difference in the pretest and posttest scores of students' critical thinking skills before and after being taught using e-modules. The results of the Paired Sample T-Test with the help of SPSS 22.0 for windows are presented in Table 3. 
Table 3. Results of Paired Sample T-Test Analysis

Paired Differences

$$
\text { 95\% Confidence }
$$

Interval of the

Std. Std. Error Difference Sig. (2-

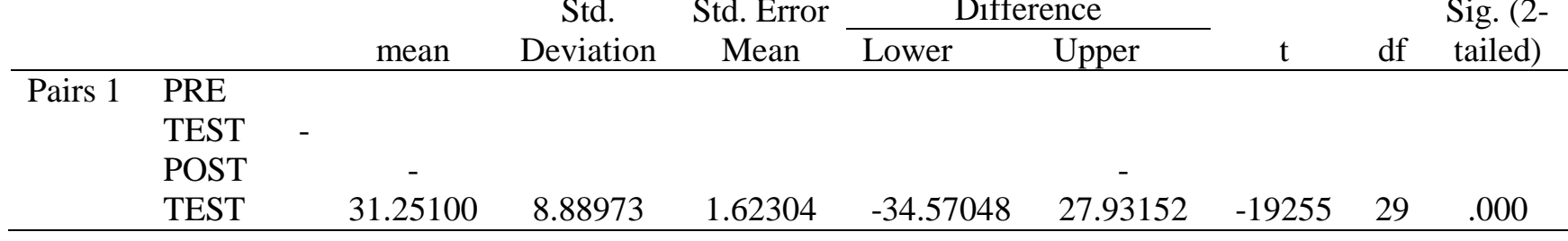

Based on Table 3 shows that the results of the Paired Sample T-Test the pretest and posttest scores of students' critical thinking skills with a significance number less than 0.05 (sig. $<0.05$ ), so the decision taken is $\mathrm{H}_{0}$ is rejected, thus it can be concluded that there are differences in students' critical thinking skills between before and after being taught with science e-modules based on socioscientific issues.

Based on the results of descriptive analysis and statistical analysis, it can be concluded that the science e-module based on socioscientific issues is effective in improving students' critical thinking skills on global warming material. Theoretically, the increase in students' critical thinking skills is caused by several factors. First, e-modules are arranged interactively with interesting animated videos. The science e-module product in this study is equipped with a quiz with automatic feedback, learning videos, music, and an attractive display, so that students' learning motivation will increase. The advantages of e-modules compared to print modules are that they are interactive, facilitate navigation, allow displaying or loading of images, audio, videos and animations and comes with formative tests or quizzes that allow immediate automatic feedback (Nufus et al. 2020). This opinion is also supported by Rozy (2017), Rosida et al. (2017) stated that interactive learning materials used in learning activities can increase students' learning motivation, and are quite effective in growing students' critical thinking skills.

Second, e-modules are integrated with socioscientific issues and critical thinking questions. Socioscientific issues are controversial issues that have a close relationship with science. This emodule is integrated with socioscientific issues in each material in order to generate students' learning motivation. This is in line with the results of research by Pratiwi et al. (2021) found that teaching materials based on socioscientific issues using interactive multimedia had met the valid, practical, and effective criteria for improving students' critical thinking skills. This finding is also supported by the research of Kurniawan et al. (2018) got the results that the integrated module on socioscientific issues was declared valid to train students' critical thinking skills.

From an empirical perspective, science emodules based on socioscientific issues are said to be effectively used in learning to improve students' critical thinking skills influenced by the presentation of material in e-modules, and Student Worksheets on e-modules are able to increase students' motivation and curiosity. The presentation of the material on the e-module is equipped with interesting learning videos. In addition, at the beginning of each chapter, controversial issues are first presented to attract students' interest in learning. The use of these socioscientific issues indirectly makes students argue to find out the truth of these issues so that indirectly students' critical thinking skills can be trained.

In addition, student worksheets on e-modules are also designed to integrate socioscientific issues at the beginning of the worksheet, this is intended to make students interested and through practical activities students are directed to seek the truth of the issues presented. The issues presented in the emodule are hoax global warming (1997-2021), planting trees does not prevent global warming (2011-2021), environmental issues and covid 19 (2020-2021), flat earth issues (1956-21). 2021), the issue of the destruction of Indonesia due to plate collision (2006-2021), eclipse due to Bhuta Kala (1983-2021), and others. Thus, students and their groups will be more active in discussing and developing each aspect of students' critical thinking skills. The science e-module is also designed with 
practice questions that are based on indicators of critical thinking skills,

In this study, several findings and obstacles were found that needed to be discussed further. The findings found in this study are as follows. First, none of the students scored zero on the pretest results. The results of the pretest of students' critical thinking skills that have been carried out show that none of the students got a score of zero, this means that all students who study in the class already have prior knowledge in this case prior critical thinking skills, even though these students have never been taught the material in question. Students who study in class do not have an empty head but have prior critical thinking skills, both obtained through experience and because the student has learned before being given the material taught by the teacher. This is in line with Yaumi (2013) which states that students come to the classroom with different and varied knowledge, skills, beliefs and attitudes. This opinion is also supported by Faizah (2016) which states that in the learning process students learn each subject not with an empty head, meaning that students already have basic knowledge about the lessons to be studied before carrying out the learning process. Based on these findings, it is very important to identify students' prior knowledge. This is supported by Suma et al., (2018) which states that to create more meaningful learning, students' prior knowledge needs to be identified.

The second finding, the students' pretest results were all in the poor and very poor categories. The results of the pretest also show that the students' prior critical thinking skills are low. This shows that students are rarely trained in skills by the teacher during learning. This statement is in line with Agnafia (2019) which states that students' critical thinking skills are still lacking or low because students are not used to being trained in indicators in critical thinking skills, in learning they still prioritize the memory process, learning is still focused on memorizing a concept, and still learning to memorize a concept, lack of applied learning in empowering students' ability to think critically. The solution is that the teacher designs learning that is more innovative and creative in learning,

The third finding, the average gain score of students' critical thinking skills is in the medium category and has not yet reached the high category. The use of science e-modules based on socioscientific issues has not been able to lead students to obtain a high category gain score. The factors that are suspected to be the cause are (1) Teachers have difficulty in practicing critical thinking skills in online learning using e-modules. Currently, learning in schools is carried out online to break the chain of the spread of COVID-19.
Based on the results of interviews and the distribution of questionnaires, it is known that teachers mostly use WhatsApp only to send assignments, and rarely use video conferencing due to internet network constraints so that teachers find it difficult to train students' critical thinking skills. This is in line with Solikhin and Fauziah (2021) who stated that the online learning process resulted in less stimulated student development because it was dominant in giving assignments so that learning was not impressed so that it had an impact on students' critical thinking skills. This opinion is also supported by Al Amin and Murtiyasa (2021) stating that distance learning makes it difficult for students to understand the lesson optimally so that it hampers students' critical thinking skills. The solution that has been done to overcome these obstacles, namely learning on WhatsApp is carried out using the science e-module that has been developed, then send screenshots of important parts of the e-module such as the socioscientific issues section and then discuss it in the WhatsApp group by asking questions that require students to think critically. Thus, the WhatsApp application is not only used to send assignments by teachers, but is used as a forum for discussion for students and teachers. (2) Limited time in implementing emodule. The implementation of the e-module in the field was carried out for four weeks. The time for implementing the e-module which is only carried out for four weeks is Poor to deliver students with low critical thinking skills to have high critical thinking skills. Critical thinking skills are skills that must be trained from an early age to students, and cannot be taught instantly. This theory is in line with Kurniahtunnisa et al. (2016), Redhana et al. (2017) stated that critical thinking skills are not a gift from birth that can be obtained instantly, but need to be developed continuously throughout life. The solution is to ask students to read the e-module before learning, and ask students to work on critical thinking skills practice questions in the e-module. (3) Students are not used to using e-modules. Previously students were accustomed to using printed books and rarely used e-modules in learning. This can be seen from some students who find it difficult to use e-modules sequentially. This is in line with the findings of Setiarini et al. (2016) stated that the obstacle in implementing e-modules is that students are not accustomed to implementing e-modules, so that when teachers ask students to use e-modules there are steps that are missed in their use. The solution is to provide explanations and video tutorials on the use of e-modules during learning. (4) students are not used to working on critical thinking skills in the form of descriptions. This is supported by Lailly et al. (2015), Huryah et al. (2017) stated that Indonesian children have 
difficulty answering questions in the form of descriptions that require reasoning, because they are very accustomed to memorizing and prefer to answer multiple choice questions compared to descriptions.

The fourth finding, the evaluation aspect has the lowest gain score. These findings indicate that students have not been able to evaluate well, where students are still not able to distinguish relevant and irrelevant information and have not been able to evaluate the statements given in the questions. This finding is in line with Ariani's (2020) finding that the evaluation indicator has the lowest achievement among other critical thinking skills indicators, which is only $13.87 \%$, which indicates that students have a deficiency in determining the right strategy in solving problems. The solution to these problems is to familiarize students with working on questions evaluating social science problems or issues in classroom learning.

\section{CONCLUSION}

Based on the results of the study, it can be said that the social issues-based science e-module is effectively used to improve students' critical thinking skills, this can be seen from the average pretest score of 43.61 in the poor category, increased in the posttest score of 74.86 in the good category, and the average gain score for critical thinking skills was 0.55 in the medium category. The results of the paired sample t-test showed a significance number smaller than 0.05 (sig. <0.05), so the decision taken was $\mathrm{H} 0$ rejected, thus it can be said that there is a significant difference in critical thinking skills between before and before being taught with science e-module based on socioscientific issues.

Based on the results of the research that has been done, the suggestions that can be put forward are (1) for education practitioners, especially in science learning, it is recommended to consider the use of science e-modules based on socioscientific issues as additional teaching materials to improve students' critical thinking skills in the revolutionary era industry and $21^{\text {st }}$ century learning. (2) for other researchers it is recommended to conduct further research using science e-modules based on socioscientific issues with the dependent variable and different materials, with a longer time allocation and covariate variables that are considered effect on the results of the study and examined with more specific research methods and designs.

\section{REFERENCES}

Agnafia, D. N. (2019). Analisis Kemampuan Berpikir Kritis Siswa dalam Pembelajaran Biologi. Florea: Jurnal Biologi dan Pembelajarannya. 6(1), 45-53.
Al Amin, Y., \& Murtiyasa, B. (2021). Analisis Kesulitan Belajar Matematika pada Proses Pembelajaran Daring Menggunakan Metode Pembelajaran Berbasis Masalah. Kontinu: Jurnal Penelitian Didaktik Matematika. 5(1), 49-65.

Ariani, T. (2020). Analysis of Students' Critical Thinking Skills in Physics Problems. Kasuari: Physics Education Journal (KPEJ). 3(1), 1-17.

Arikunto, S. (2015). Dasar-dasar Evaluasi Pendidikan. Jakarta: Bumi Aksara

Artifasari, E. P., Rahayu, S., \& Mustikasari, V. R. (2017). Pengembangan Bahan Ajar IPA dengan Mengeksplisitkan Hakikat Sains (NOS) dan berpikir kritis pada Topik Lapisan Bumi. In Prosiding Seminar Nasional Pembelajaran Ipa Ke-2 Tahun 2017. 182187.

Ennis, R. H. (1991). Goal for a Critical Thinking Curriculum and Its Assessment. In Arthur L. Costa (Ed.), Developing Minds (Revised Edition). Alexandria, VA: ASCD.

Evren, A. Y. (2018). Advantages and Disadvantages of Socioscientific Issue-Based Instruction in Science Classrooms. International Online Journal of Education and Teaching (IOJET). 5(2). 361-374.

Facione, P. A. 1990. Critical Thinking: A Statement of Expert Consensus for Porpuse of Educational Assessment and Instruction. Research Findings and Recommendations Prepared for the Committee on Pre-College Philosophy of the American Philosophical Association. Fullerton: California State University.

Faizah, K. (2016). Miskonsepsi dalam pembelajaran IPA. Jurnal Darussalam: Jurnal Pendidikan, Komunikasi dan Pemikiran Hukum Islam, 8(1), 115-128.

Febrianti, K. V., Bakri, F., \& Nasbey, H. (2017). Pengembangan Modul Digital Fisika berbasis Discovery Learning pada Pokok Bahasan Kinematika Gerak Lurus. Jurnal Wahana Pendidikan Fisika. 2(2). 18-26.

Hake, R. R. (1998). Interactive Engagement Versus Traditional Methods: A Six Thousand Student Survey of Mechanics Test Data for Introductory Physics Courses. American Journal of Physics. 66(1). 64-74.

Hayudiyani, M., Muchamad, A., \& Medika, R. (2017). Identifikasi Kemampuan Berpikir Kritis Siswa Kelas X TKJ Ditinjau dari Kemampuan Awal dan Jenis Kelamin Siswa di SMKN 1 Kamal. Jurnal Ilmiah Edutic. 4(1). 20-27.

Huryah, F., Sumarmin, R., \& Effendi, J. (2017). Analisis Capaian Literasi Sains Biologi 
Siswa SMA Kelas X Sekota Padang. Jurnal Eksakta Pendidikan (JEP). 1(2), 72-79.

Jaenudin, A., \& Murwaningsih, T. (2017). The Effectiveness of the E-Module of Economics Learning on Problem-Based Learning used to Improve Students' Learning Outcomes. In International Conference on Teacher Training and Education 2017 (ICTTE 2017), Atlantis Press. 58(1). 30-36.

Jufrida, J., Basuki, F. R., Rinaldo, F., \& Purnamawati, H. (2020). Analisis Permasalahan Pembelajaran Ipa: Studi Kasus Di Smpn 7 Muaro Jambi. Jurnal Pendidikan Sains (JPS). 8(1), 50-58.

Kemendikbud. (2017). Panduan Praktis Penyusunan E-Modul. Jakarta: Direktorat Jenderal Pendidikan Dasar Dan Menengah Kementerian Pendidikan Dan Kebudayaan

Kurniahtunnisa., Kusuma, D., \& Rahayu, U. (2016). Pengaruh Model Problem Based Learning Terhadap Kemampuan Berpikir Kritis Siswa Materi Sistem Ekskresi. 5(3). 310-318.

Kurniawan, J. A., Mahardika, I. K., \& Supene. (2018). The Validity of Socioscientific Issues-Based Science Module for Students' Critical Thinking Skills. Internasional Journal of Advance Research and Innovative Ideas in Education. 4(5). 445-450.

Laili, I. (2019). Efektivitas Pengembangan E-Modul Project Based Learning Pada Mata Pelajaran Instalasi Motor Listrik. Jurnal Imiah Pendidikan dan Pembelajaran.3(3). 306315.

Lailly, N. R., \& Wisudawati, A. W. (2015). Analisis Soal Tipe Higher Order Thinking Skill (HOTS) dalam Soal UN Kimia SMA Rayon B Tahun 2012/2013. Jurnal Kaunia. 11(1), 27-39.

Martin, M. O., Ina, V.S. M., Pierre, F., \& Martin, H. (201)5. TIMSS 2015 International Result in Science. IEA.

Nufus, H., Susilawati, S., \& Linda, R. (2020). Implementation of E-Module Stoiciometry Based on Kvisoft Flipbook Maker for Increasing Understanding Study Learning Concepts of Class X Senior High School. Journal of Educational Sciences. 4(2), 261-272.

Nuryanti, L., Siti, Z. \& Markus, D. (2018). Analisis Keterampilan Berpikir Kritis Siswa SMP. Jurnal Pendidikan: Teori, Penelitian, dan Pengembangan. 3(2). 155-158.

OECD 2019. PISA (2018). Assessment and Analytical Framework, PISA. Paris: OECD Publishing.

Parliani, S. (2016). Pengaruh Penggunaan Lembar Kerja Siswa (LKS) Berbasis Keterampilan Proses Sains terhadap Keterampilan Berpikir
Kritis Siswa Kelas X SMA Negeri 1 Gunungsari pada Materi Reaksi Redoks (Doctoral dissertation, Universitas Mataram).

Partnership for $21^{\text {st }}$ Century Learning. (2019). Framework for $21^{\text {st }}$ Century Learning.

Perdana, F. A., Sarwanto, S., Sukarmin, S., \& Sujadi, I. (2017). Development of E-Module Combining Science Process Skills and Dynamics Motion Material to Increasing Critical Thinking Skills and Improve Student Learning Motivation Senior High School. International Journal of Science and Applied Science: Conference Series 1(1). 45-54.

Permendikbud. (2016). Standar Proses.[Online]. Available on https://bsnpindonesia.org/wp/uploads/2009/06/Permendi kbud_Tahun2016_Nomor022_Lampiran. pdf. Diakses pada tanggal 1 September 2020.

Pratiwi, E., Suryanti., \& Sudibyo, E. (2021). Pengembangan Bahan Ajar Berbasis Socio Scientific Issues dengan Menggunakan Multimedia Interaktif untuk Melatih Keterampilan Berpikir Kritis Siswa Kelas V Sekolah Dasar. Jurnal Education And Development. 9(1), 273-273.

Puspitasari, A. D. (2019). Penerapan Media Pembelajaran Fisika menggunakan Modul Cetak dan Modul Elektronik pada Siswa SMA. Jurnal Pendidikan Fisika. 7(1). 17-25.

Pustekkom. (2018). Surat Edaran Nomor 9 Tahun 2018 Tentang Pemanfaatan Rumah Belajar. Jakarta: Pustekom

Redhana, I. W., Karyasa, I.W., \& Fitria, A. (2017). Development of Critical Thinking Disposition Inventory. Advances in Social Science, Education and Humanities Research Proceedings of the 2nd International Conference on Innovative Research Across Disciplines (ICIRAD 2017). Vol 134. 195198.

Rosida, R., Fadiawati, N., \& Jalmo, T. (2017). Efektivitas Penggunaan Bahan Ajar E-Book Interaktif dalam Menumbuhkan Keterampilan Berpikir Kritis Siswa. Jurnal Pembelajaran Fisika. 5(1), 1-11.

Rostikawati, D. A., \& Permanasari, A. (2016). Rekonstruksi Bahan Ajar dengan Konteks Socio-Scientific Issues pada Materi Zat Aditif Makanan untuk Meningkatkan Literasi Sains Siswa. Jurnal Inovasi Pendidikan IPA. 2(2), 156-164.

Rozy, A. F. (2017). Pengembangan Media Pembelajaran Elektronika Berbasis 3D Pageflip pada Mata Pelajaran Penerapan Rangkaian Elektronika Di SMK Negeri 1 Kediri. Jurnal Pendidikan Teknik Elektro. 6(1), 1-11. 
Sadler, T. D. (2004). Informal Reasoning Regarding Socioscientific Issues: A Critical Review of Research. Journal of Research in Science Teaching. 41(5). 513-536.

Saputra, H., Arif, H., \& Munzil. (2016). Profil Keterampilan Berpikir Kritis Siswa SMPN 7 Pasuruan. P Pros. Semnas Pend. IPA Pascasarjana UM. Vol 1. 943-949.

Savira, Y. M., Budi, A. S., \& Supriyati, Y. (2019). Pengembangan E-Modul Materi Momentum dan Impuls Berbasis Process Oriented Guided Inquiry Learning (POGIL) untuk Meningkatkan Kemampuan Berpikir Tingkat Tinggi Siswa SMA Kelas X. in PROSIDING SEMINAR NASIONAL FISIKA (EJOURNAL) (Vol. 8, pp. SNF2019-PE).

Serevina, V., Sunaryo., Raihanati., Astra, I.M., \& Sari, I. J. (2018). Development of E-Module Based on Problem Based Learning (PBL) on Heat and Temperature to Improve Student's Science Process Skill. TOJET: The Turkish Online Journal of Educational Technology. 17(3). 26-36.

Setiarini, K. P., Agustini, K., Sunarya, I. M. G., \& Kom, S. (2016). Pengaruh E-Modul Berbasis Metode Pembelajaran Problem Based Learning Terhadap Hasil dan Motivasi Belajar Siswa pada Mata Pelajaran Pemrograman Dasar (Studi Kasus: Kelas X Multimedia di SMK Negeri 3 Singaraja). KARMAPATI (Kumpulan Artikel Mahasiswa Pendidikan Teknik Informatika). 5(2), 277-287.

Solikhin, M., \& Fauziah, A. N. M. (2021). Analisis Kemampuan Berpikir Kritis Siswa SMP pada Pelajaran IPA saat Pembelajaran Daring Selama Pandemi Covid-19. Pensa: E-Jurnal Pendidikan Sains. 9(2), 188-192.

Suma, K., Sadia, I W., \& Pujani, N. M. (2018). The Identification of The $11^{\text {th }}$ Grade Students' Prior Knowledge of Electricity Concepts. Journal of Physics: International Conference on Mathematics \& Natural Science. 10(1),1-7

World Economic Forum. (2018). The Future of Jobs Employment, Skills and Workforce Strategy for the $4^{\text {th }}$ Industrial Revolution.

Yaumi, M. (2013). Prinsip-prinsip Desain Pembelajaran. Jakarta: Kencana Prenadamedia Group.

Yulizar, N., \& Munzil, S. (2017). Pengembangan Bahan Ajar Digital Materi Sistem Reproduksi pada Manusia Untuk Siswa Kelas IX SMP/MTs. In Prosiding Seminar Nasional Pembelajaran Ipa Ke-2 Tahun 2017 (p. 252).

Yusliani, E., Burhan, H. L., \& Nafsih, N. Z. (2019). Analisis integrasi keterampilan abad Ke-21 dalam sajian buku teks fisika SMA Kelas XII
Semester 1. Jurnal Eksakta Pendidikan (JEP), 3(2), 184-191. 